\title{
Haji Bunka: A Cultural Approach to Support Social and Physical Distancing Policies Against The COVID-19 Pandemic for Students at The Faculty of Language and Communication Universitas Harapan Medan
}

\author{
Mhd. Pujiono*, Murniati Br. Barus, Nelvita, Vivi Adryani Nasution, Intan Erwani \\ Japanese Literature Study Program, Faculty of Cultural Science, University of Sumatera Utara, Medan, \\ Indoneisia
}

Submitted: December $7^{\text {th }}$ 2020; Revised: March 5th 2021; Accepted: December $15^{\text {th }} 2021$

\begin{abstract}
Keywords:
COVID-19

Cultural

approach

Haji bunka

Implementation

Socialization

Abstract Community service activities for students at the Faculty of Language and Communication, Universitas Harapan (FBK UNHAR) Medan to implement haji bunka towards social distancing policies amid the COVID-19 pandemic are an appropriate activity in providing an understanding of Japanese shame culture (haji bunka) for FBK UNHAR students and its implementation to prevent the spread of COVID-19. FBK UNHAR is a private higher education institution in Medan that faces challenges in implementing education on campus during the pandemic and the government's new normal performance. In this service, the team has conducted socialization about implementing the haji bunka on campus, such as replacing handshakes with ojigi, wearing masks, classifying garbage, and other activities that can help prevent the spread of the coronavirus. Offline socialization activities were carried out through lecture methods and discussions with students. Following the socialization, the community service team and students agreed to incorporate the haji bunka into daily student activities on campus and the protocol for implementing lectures if it is applied offline.
\end{abstract}

\section{INTRODUCTION}

The new coronavirus, which was later designated by the World Health Organization (WHO) as COVID-19, has hit the world to a pandemic level. In Indonesia, corona sufferers on May 1, 2020, reached 10,551 cases. 800 people died, while 1,591 people recovered (COVID19.go.id). Although the government, through President Joko Widodo (Widiyani, 2020), predicts the coronavirus will end in July 2020, the pandemic is still sweeping the world. For this reason, various handling policies, such as the Social Distancing program, which in Indonesia is called Pembatasan Sosial Berskala Besar or PSBB (Large-Scale Social Restrictions), have changed social and cultural life in Indonesia a lot.

Culture is concerned with perception and affects interpersonal interactions or communication with others. The axiom of communication states that humans cannot live if they do not communicate (Waite Bowers
\& Bradac, 1981). This condition is also the reason. Even though people are encouraged to stay at home and avoid crowds, the community will still be psychologically inclined to ignore all of these limitations.

Furthermore, changes can be observed through various elements of universal culture (Koentjaraningrat, 2007). the religious system has asked humanity to abstain from worshiping in places of worship. In the economic system (livelihoods), traders who usually sell directly may only be able to sell online now. As in the language system, several words have new meanings in society, such as isolation, pandemic, etc. Meanwhile, general knowledge related to body immunity, disinfectants, and so on has received increasing attention. Living equipment systems and technology have also changed, for example, providing hand sanitizers at home or in bags. These are all

ISSN 2460-9447 (print), ISSN 2541-5883 (online)

${ }^{*}$ Corresponding author : Mhd. Pujiono

Japanese Literature Study Program, Faculty of Cultural Science, University of Sumatera Utara, JL. Universitas, No. 19, Padang Bulan, Medan Baru, Medan, Sumatera Utara 20155, Indonesia

Email: mhd.pujiono@usu.ac.id 
descriptions of societal changes or shifting habits. As a result of the COVID-19 pandemic, a new way of life emerged in society. The focus of the discussion, in this case, is the change in society in the university environment.

Recently, the government, through President Joko Widodo's speech, has implemented a new normal in several provinces, districts, and cities. President Joko Widodo stated that the new normal was implemented in areas with a low coronavirus transmission (Bayu, 2020). Japan has already done the same thing through Prime Minister Shinzo Abe's decision to lift the state of emergency in the capital and four prefectures on May 25,2020 . They claim victory against COVID-19 with this measure because it has kept total infections relatively low, around 16,600 cases (Shalihah, 2020). Based on the people's behavior, habits, and culture that support the government's efforts, Japan is more responsive in overcoming this problem. Hence, by looking at Japanese society's culture, we can learn how to deal with the pandemic.

The new normal is expected to bring about new behaviors on cleanliness and social interactions in the society to create a new normal condition. Changes in social and cultural behavior are also followed by various problems of social life in Indonesia. Therefore, attempts to support the government's idea in the new normal also require a segmented cultural approach to specific groups of society, for example, student groups.

Students from the Faculty of Language and Communication, Universitas Harapan Medan (FBK UNHAR), can implement a cultural approach to dealing with the pandemic. One of the study programs at FBK UNHAR is the Japanese language study program. Japanese language courses are also taught in other study programs, such as English literature. As a result, more or fewer students are already familiar with the characteristics of the Japanese language and society, for instance, in terms of cleanliness, manners, and so on. As a result, the Japanese cultural approach is regarded as an appropriate model for preventing COVID-19 transmission.

There is a term known as haji bunka (恥文化) or shame culture in Japanese culture. haji, which is one of the traditional Japanese people's traditional concepts, plays an essential role in regulating and controlling Japanese society's mechanism of life patterns. According to Benedict (2005), shame or haji is a reaction to criticism or other people's views. In Japanese society, it becomes an essential consideration in managing behavior patterns. In other words, the haji is the key to maintaining stability in Japanese society and in every individual Japanese society. Kustianty (Rahman, 2012) said that haji bunka's concept is closely related to society's life and groups or one individual to another. Haji can occur when there are irregularities or irregularities. If an individual has a relationship with one another, there is a tendency that they act after other individuals in order to avoid bringing up a view and criticism. As a result, they tend to not act on their own beliefs and more on actions that follow others. This Haji culture forms the basis of many Japanese behavior and habits, such as saying greetings by bowing the body (ojigi) and maintaining the boundaries of interaction between people.

This service aims to provide students with an understanding of the haji bunka and invite students to apply to the Faculty of Language and Communication at Universitas Harapan Medan. As a result, the main purpose of the activity can be accomplished by taking a cultural approach to preventing COVID-19 transmission on campus.

\section{METHOD}

The team intends to carry out socialization and teaching activities in the classroom to implement the haji bunka towards social distancing policies for FBK UNHAR students amid the COVID-19 pandemic. This measure depends on the current conditions and situation regarding government regulations concerning the Large-Scale Social Restrictions. Assume that several new normal stages have been implemented, making it possible to hold meetings in class. The team will carry them out following the applicable rules and protocols. However, additional assistance is provided online through Google Meet and Zoom.

Thirty FBK UNHAR students from the English and Japanese language study programs participated in the two-day socialization event at the university. Participants were chosen through interviews conducted in collaboration with service partners from the Faculty of Language and Communication at Universitas Harapan Medan (FBK UNHAR). The lecture and discussion or question and answer method were used in this outreach activity (Dimyati \& Mudjiono, 2012).

\subsection{Lecture method}

The lecture method explains the fundamentals of the haji bunka in Japan and its relationship to modern Japanese society's behavior. This method also emphasizes efforts to motivate participants to adopt the haji bunka.

\subsection{Discussion and Q\&A}

The discussion and Q\&A method were conducted because the participants needed to know their ability to receive an explanation of the knowledge given. This method allows the participants to understand Japanese culture, especially shame culture (haji bunka), as possible. 


\section{RESULT AND DISCUSSION}

The activities on implementing the haji bunka on social distancing policies amid the COVID-19 pandemic for the Faculty of Language and Communication (FBK) Universitas Harapan (UNHAR) were socialization and discussion with the academic community, consisting of lecturers and program students. Study of English Literature and Japanese Language. The results of the socialization and discussion will be explained in the following sub-chapters.

\subsection{Haji bunka socialization}

The haji bunka socialization for students and lecturers at FBK UNHAR was held for the first time on Tuesday, September 15, 2020, at 10:00 West Indonesian Time. A total of 30 students from two different study programs, namely Japanese Pronunciation and English Literature, participated in the socialization activities. The meeting was held online the next day through Zoom Meeting (Figure 2).

Throughout its implementation, the team also strove for proper and correct health protocols during the COVID-19 pandemic: the team prepared hand sanitizers, masks, and face shields for the participants during the activity. Seats for the participants are also separated with sufficient distance to avoid being physically close with one another. Therefore, this activity's implementation provided the participants a sense of security and comfort even during the pandemic (Figure 1)

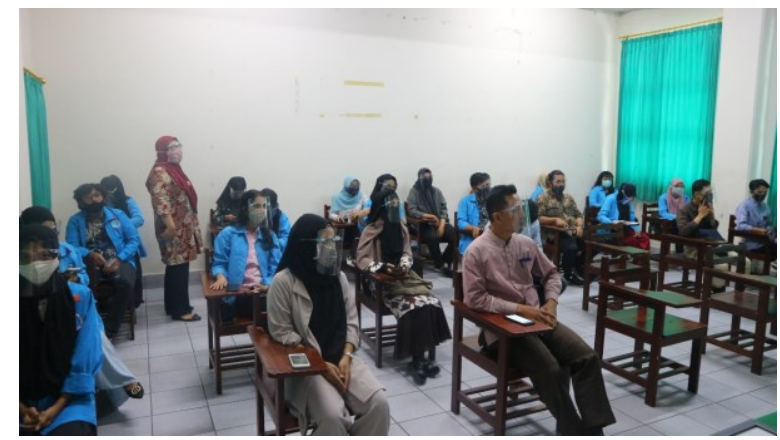

Figure 1. During the socialization activity, the participants obeyed the Health Protocol as they listened to the provided material

The team presented the Dean with the award certificate following the socialization (Figure 3 ). In addition, the Dean and students have agreed to implement the haji bunka in campus activities.

The community service team delivered the socialization materials. The team leader, as a presenter, could effectively convey the concept of the haji bunka, which became the topic of this activity. Haji bunka is a cultural concept of Japanese society that the team has mastered as speakers in socialization.

The speaker's points revolved around the concept of shame in Japanese society, which consists of kouchi (公 恥) and shichi (私 恥). Kouchi's shyness is a reaction to criticism from others. People are embarrassed if they are openly ridiculed and rejected or imagine themselves being made fun of. In both cases, shame is a potent sanction. However, it requires an audience or an audience in people's fantasies (Benedict, 2005). Ruth Benedict (2005) also explains that shame will arise when someone cannot properly fulfill their obligations. Therefore, the duty includes a person's debt from the greatest to the smallest, called on (恩). On means a debt or a burden that he must carry as best as possible.

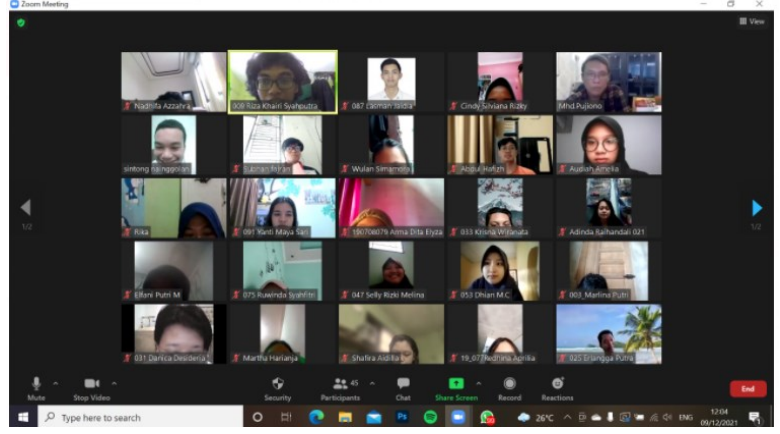

Figure 2. Implementation of discussions about haji bunka on the second day through Zoom Meeting

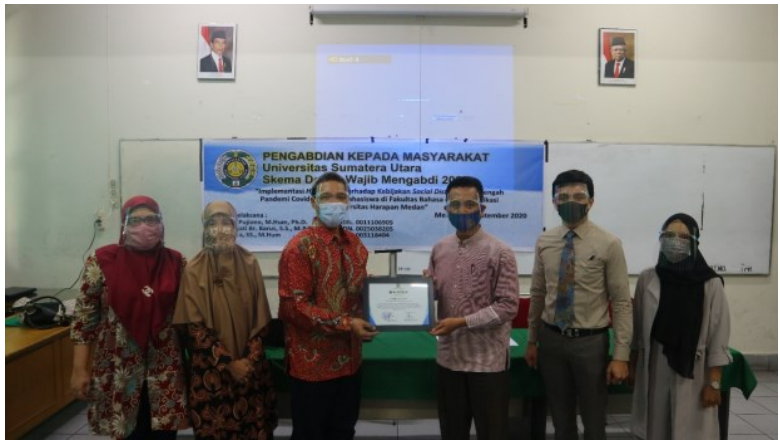

Figure 3 . The team gave a certificate to the Dean

Meanwhile, Sichi is an embarrassment that arises when a person gets complimented. When faced with rejection from others, Japanese people feel embarrassed, but when they receive praise and special attention from others, they feel ashamed. This is implemented in all aspects of Japanese people's lives and has become a habit that supports social or physical distancing policies to prevent COVID-19 transmission.

\subsection{Discussion on the implementation of haji} bunka on campus

Following the explanation from the team, a discussion about the implementation of the haji bunka, which can be applied in the campus environment, was conducted. The participants, both students and lecturers, actively inquired and expressed their opinions during the discussion.

The following are the agreements reached in implementing the haji bunka in the campus environment to support the government's social distancing and new normal policies. 


\section{Changing the habit of shaking hands to ojigi (书辞儀)}

Ojigi is a bowing gesture used in Japanese culture to show respect to others. It is highly appropriate to substitute Indonesian people's habit of shaking hands while greeting, requesting permission, and saying goodbye to the Ojigi academic community (Amanatin et al., 2020).

According to the situation at hand, the participants were also informed about the philosophical basis, meaning, and procedures of the proper and correct ojigi. For example, how low is the bow when only reprimanding a friend or lecturer, when asking for permission, apologizing, and so on.

\section{Wearing a mask while on campus}

Masks have long been used by the Japanese people to implement the haji bunka. Most of them used to mask even before the COVID-19 pandemic. They felt embarrassed when they spread various viruses, such as influenza or even terrible breath that made other people uncomfortable. The rules for wearing masks on campus following the health protocol were agreed upon as a result of the discussion. Wearing a mask is more about self-accustoming; not wearing masks is seen as a rule that, if violated, results in sanctions. It happens because it is common to see students wearing masks but lowering them under their mouths when conversing with others.

\section{Orderly and Organized}

Japanese people's culture must be implemented in a campus environment when they feel embarrassed if they are disorganized, such as waiting in line and walking in public places. When someone is disorganized, there must be a sense of shame that it will disturb and harm others.

\section{Handwashing habits}

Soap and cleaner are always available in public toilets, office entrances, and almost every public space in Japan. Using a sanitizer, such as a hand sanitizer, is prevalent enough to prevent the virus from spreading. In the toilet, people wash their hands then clean and wipe the sink area to make the next user comfortable. This behavior is appropriate to be implemented in a campus environment.

The real outcome that can be felt from this community service is the resolution of problems at the Faculty of Language and Communication, Universitas Harapan, related to efforts to address social or physical distancing policies, specifically by implementing haji bunka on campus. It is demonstrated by the agreement on several things of the haji bunka implementation to be immediately implemented in the faculty environment. As evidence, an output can be accessed related to this service activity, which is a video published online on Youtube (https://youtu.be/t4YwL5YrtD0).

\section{CONCLUSION}

Community service activities implementation of haji bunka on social distancing policies in the middle of the COVID-19 pandemic for students at the Faculty of Language and Communication, Universitas Harapan Medan that the team has implemented has a positive impact in increasing understanding and awareness of the academic community about the importance of selfadjustment against government regulations and maintaining health during the pandemic.

In its implementation, this activity can be one of the initial steps for the academic community at FBK UNHAR in implementing various activities based on the concept of haji bunka to prevent COVID-19 spread. The implementation of various activities has been mutually agreed upon as rules for social interaction and provisions for supporting cleanliness facilities in the FBK UNHAR area.

\section{ACKNOWLEDGMENT}

This activity is fully supported materially by the Lembaga Pengabdian Masyarakat (LPM) at the University of Sumatera Utara (USU). Therefore, we express our gratitude to the Rector of the University of Sumatera Utara and the Chairperson of LPM USU. Additionally, we appreciate the permission and facilitation of the activity by the Faculty of Languages and Communications, Universitas Harapan Medan.

\section{REFERENCES}

Amanatin, E. L., Wulida, N. R., Mukti, H., Prasetyo, K. B., Putri, N. A., \& Pramono, D. (2020). Dari Salaman ke Senyuman: Dampak Kebijakan Kesehatan Global terhadap Komunitas Lokal di Era Pandemi. Umbara, 5(2), 118. https://doi.org/10.24198/umbara.v5i2.30656

Bayu, D. J. (2020, May 27). Jokowi Bakal Berlakukan New Normal di Sejumlah Daerah, Ini Syaratnya. Retrieved from katadata.com website: https://katadata.co.id/berita/2020/05/27/jokowibakal-berlakukan-new-normal-di-sejumlahdaerah-ini-syaratnya

Benedict, R. (2005). The Chrysanthemum and The Sword: Patterns of Japanese Culture (First Mari). Boston and New York: Houghton Mifflin Harcourt Publishing Company.

Dimyati, \& Mudjiono. (2012). Belajar Dan Pembelajaran. Jakarta: Rineka Cipta.

Koentjaraningrat. (2007). Manusia dan Kebudayaan Di Indonesia. Jakarta: Djambatan.

Rahman, A. (2012). Korelasi konsep haji dalam peristiwa pengunduran diri pejabat pemerintah Jepang (studi kasus pengunduran diri menteri rekonstruksi Ryu Matsumoto). JAPANOLOGY, 1(1), 103-113. Retrieved from http://journal.unair.ac.id/JPLG@korelasi- 
konsep-haji-dalam-peristiwa-pengunduran-diripejabat-pemerintah-jepang-(-studi-kasuspengunduran-diri-menteri-rekonstruksi-ryumatsumoto-)-article-4232-media-44-category8.html

Shalihah, N. F. (2020, May 29). Jepang Sudah Mulai New Normal, seperti Apa Praktiknya? Retrieved from KOMPAS.com website: https://www.kompas.com/tren/read/2020/05/29/ 085500065/jepang-sudah-mulai-new-normalseperti-apa-praktiknya

Waite Bowers, J., \& Bradac, J. J. (1981). Issues in Communication Theory: A Metatheoretical Analysis. Annals of the International Communication Association, 5(1), 1-27. https://doi.org/10.1080/23808985.1981.119238 37 